(REVIEW ARTiCle)

\title{
The role of human resources management in organizational perspective
}

\author{
Sukmo Hadi Nugroho* \\ Esa Unggul University Jakarta, Indonesia.
}

Global Journal of Engineering and Technology Advances, 2022, 10(03), 012-018

Publication history: Received on 21 January 2022; revised on 28 February 2022; accepted on 02 March 2022

Article DOI: https://doi.org/10.30574/gjeta.2022.10.3.0040

\begin{abstract}
This research aims to determine the role of human resource management in organizations. This research uses a literature review method. From the discussion, it can be concluded that human resource management has three functions, namely managerial functions, operational functions, and functions to achieve organizational goals in an integrated manner. Meanwhile, the duties of human resource management are staff procurement, human resource development, compensation management, occupational safety and health, labor relations, and industrial relations. The main objective of human resource management is to increase the contribution of human resources (employees) to the organization. It can be understood that all organizational activities in achieving its goals depend on the humans who manage the organization. Therefore, employees must be managed properly so that they can assist the organization in achieving the organizational goals that have been determined. To achieve the objectives of human resource management carried out by HR managers, and managers on all lines of the company and outsourcing.
\end{abstract}

Keywords: HRM; Organization; Politics; Economics; Law; Socio-Cultural; Administration; Technology

\section{Introduction}

Human resource management is a process of dealing with various problems in the scope of employees, employees, laborers, managers, and other workers to be able to support the activities of the organization or company to achieve predetermined goals. Therefore managers must ensure that the company or an organization has the right workforce at the right place, and at the right time, who can complete tasks that will help the company achieve its overall goals effectively and efficiently (Bandono, 2021).

Human resource management (HRM) is the design of formal systems within an organization to ensure the effective and efficient use of human talent to achieve organizational goals. It doesn't matter whether the company is a large company with 10,000 employees or a small non-profit organization with 10 employees they still have to be paid, which means a good and legal compensation system is needed.

Every HRM activity requires thinking and understanding about what will work well and what will not. In an environment where workforce challenges are constantly changing, laws are changing, and the needs of employers are changing, HRM must continue to change and evolve (Becker \& Huselid, 2006).

Power The underlying concept is that every employee is a human being, not a machine, and not merely a business resource. The study of HR management combines several disciplines such as psychology, sociology, and others. HRM also concerns the design and implementation of the digestive system, employee preparation, employee development, career management, performance evaluation, employee compensation, and good employee relations.

\footnotetext{
${ }^{*}$ Corresponding author: Sukmo Hadi Nugroho

Esa Unggul University Jakarta Indonesia.

Copyright $(2022$ Author(s) retain the copyright of this article. This article is published under the terms of the Creative Commons Attribution Liscense 4.0.
} 
Human resource management involves all management decisions and practices that directly affect human resources. HRM is needed to improve the effectiveness of human resources in the organization. The goal is to provide the organization with an effective work unit.

To achieve this goal, the study of personnel management will show how companies should get, develop, use, evaluate, and maintain the right number (quantity) and type (quality) of employees. HRM discusses the great potential of the human workforce which is the driving force behind the supporting factors of management activities that must be utilized as best as possible through synergies with the environment. Undeniably, technological changes are very fast, forcing organizations to adapt to their business environment (Devanna et al, 1981).

Writing this paper aims to find out how the role of human resource management in organizations. Furthermore, the writing of this paper uses the method of literature review (library research).

\section{Material and methods}

\subsection{Definition of HRM}

HRM is the development and utilization of personnel (employees) for the effective achievement of individual, organizational, community, national, and international goals and objectives. Human resource management can be defined as a process and an effort to recruit, develop, motivate, and evaluate the overall human resources needed by the company in achieving its goals (Sule \& Saefullah, 2005).

Human resource management is defined as planning, organizing, mobilizing, and supervising the procurement, development, compensation, integration, maintenance, and termination of employment to achieve the company's organizational goals in an integrated manner (Umar, 2001).

\subsection{HRM Scope}

The scope of HRM includes all activities related to human resources in the organization, as stated by Rafiei \& Davari (2015) that: "....all decisions which affect the workforce concern the organization's human resource management function....". Activities related to this HRM generally include (1) Organizational Design, (2) Staffing, (3) Reward System, benefits, and compliance, (4) Performance Management, (5) Employee and Organizational Development, (6) Communication, and Public Relations. Meanwhile, the activities that are generally included in the scope of HRM are

\subsubsection{Organizational Design}

- Human Resource Planning

- Job analysis

- Job plan

- Teamwork (socio-technical system)

- Information systems

\subsubsection{Staffing}

- Recruit/interview/hire

- Affirmative action

- Promotion/transfer/spare

- Outplacement services

- Appointment/orientation

- Worker selection methods

\subsubsection{Reward system, benefits, and compliance}

- Health/medical services

- Complaints/discipline procedures

- Compensation administration

- Wage/payroll administration

- Administration of insurance benefits

- $\quad$ Profit-sharing/pension plans

- Working relationships 


\subsubsection{Formation Management}

- $\quad$ Management assessment/MBO

- Improvement/productivity programs

- $\quad$ Client-focused performance appraisal

\subsubsection{Job and organizational development}

- Development and supervision/management

- Career planning/development

- Work coaching/assistance programs

- $\quad$ Skills training, non-management

- $\quad$ Retirement preparation programs

- $\quad$ Research on attitudes

\subsubsection{Communication and Public Relations}

- Information systems/reports/records of human resources

- Worker communication/publication

- Suggestion system

- Human resource research

\subsection{HRM Function}

According to Kabene et al (2006), human resource functions consist of

\subsubsection{Staffing/Employment}

This function consists of three important activities, namely planning, drawing, and selecting human resources. Managers are responsible for anticipating human resource needs. As companies grow, managers are becoming more dependent on the human resources department to gather information about the composition and skills of the current workforce. Although the recruitment process is carried out entirely by the human resources department, other departments are still involved by providing descriptions of the job specifications to assist the recruitment process.

In the selection process, the human resources department screens through interviews, tests, and investigates applicants' backgrounds. The responsibility of the human resources department for manpower procurement is increasing with the law regarding equal employment opportunities and various conditions required by the company.

\subsubsection{Performance Evaluation}

Human resource performance appraisal is the responsibility of the human resources department and managers. Managers bear the primary responsibility for evaluating their subordinates and the human resources department is responsible for developing an effective form of performance appraisal and ensuring that the performance appraisal is carried out by all parts of the company.

The human resources department also needs to train managers on how to set good performance standards and make accurate performance appraisals (Nugroho \& Pudiastuti, 2021).

\subsubsection{Compensation}

In terms of compensation/reward, good coordination is needed between the human resources department and the managers. Managers are responsible for salary increases, while the human resources department is responsible for developing a good salary structure. A compensation system that requires a balance between payments and benefits provided to workers. Payments include salaries, bonuses, incentives, and profit-sharing received by employees. Benefits include health insurance, life insurance, leave, and so on. The human resources department is responsible for ensuring that the compensation provided is competitive among similar companies, fair, appropriate. with applicable law (eg: UMR), and provide motivation (Condrey, 2005).

\subsubsection{Training and Development}

The human resources department is responsible for helping managers become good coaches and advisors to their subordinates, creating effective training and development programs for both new (orientation) and existing (skills 
development) employees, being involved in the training and development program, estimating the company's need for training and development programs, and evaluate the effectiveness of training and development programs. The responsibility of the human resources department in this case also concerns the issue of termination of employment. This responsibility helps with corporate restructuring and provides solutions to conflicts that occur within the company (Reza \& Nugroho, 2020).

\subsubsection{Employee Relations}

In a company that has a union, the human resources department plays an active role in negotiating and dealing with issues of agreement with the union. Helping companies deal with unions is the responsibility of the human resources department. After the approval is agreed upon, the human resources department assists the managers on how to take care of the approval and avoid more complaints (Gomes, 2016). The main responsibility of the human resources department is to avoid unhealthy practices (eg strikes, demonstrations).

In companies that do not have a union, the human resources department is needed to be involved in employee relations. In general, employees do not join a union if their salary is adequate and they believe that the company is responsible for their needs. The human resources department in this case needs to ensure that employees are treated well and whether there is a good and clear way to deal with complaints. Every company, whether it has a trade union or not, needs a firm way to improve discipline and resolve complaints to solve problems and protect workers (Nugroho \& Afifah, 2021).

\subsubsection{Safety and Health}

Every company is obliged to have and implement a safety program to reduce unwanted incidents and create healthy conditions. Workers need to be reminded continuously about the importance of safety at work. An effective work safety program can reduce the number of accidents and improve the health of the workforce in general. The human resources department has primary responsibility for conducting training on occupational safety, identifying and correcting conditions that endanger workers, and reporting work accidents.

\subsubsection{Personnel Research}

To improve the effectiveness of the company, the human resources department analyzes individual and company problems and makes appropriate changes. Problems that are often considered by the human resources department are the causes of employee absenteeism and tardiness, how good the recruitment and selection procedures are, and the causes of workforce dissatisfaction. The human resources department is responsible for collecting and analyzing information about this matter. The results are used to assess whether existing policies need to be changed or not.

\subsection{HRM Goals}

HRM objectives consist of four objectives, namely: (Soliman \& Spooner, 2000).

\subsubsection{Organizational Goals}

It is aimed at recognizing the existence of human resource management (HRM) in contributing to the achievement of organizational effectiveness. Although formally a human resources department was created to assist managers, managers are still responsible for employee performance. The human resources department assists managers in dealing with matters relating to organizational human resources. Functional Purpose.

Aimed at maintaining departmental contributions at a level appropriate to the needs of the organization. Human resources become worthless if human resource management has criteria that are lower than the level of organizational needs.

\subsubsection{Social Goals}

Aims to be ethically and socially responsible to the needs and challenges of society through actions to minimize negative impacts on the organization. The failure of an organization to use its resources for the benefit of society can cause obstacles.

\subsubsection{Personal Purpose}

Intended to assist employees in achieving their goals, at least goals that can enhance individual contributions to the organization. Employee personal goals must be considered if employees are to be retained, retired, or motivated. If 
personal goals are not considered, employee performance and satisfaction may decline and employees may leave the organization.

\subsection{Human Resource Management Process}

The human resource management process is all processes related to the efforts made from human resource planning, recruitment, signing of work contracts, placement of workers, to coaching and developing the workforce to place and maintain workers in certain positions and qualifications and responsibilities following the requirements given to the workforce (Sharma et al, 2009).

Broadly speaking, the HR management process is divided into five main functional sections consisting of:

- Human Resource Planning

- $\quad$ Personnel Procurement

- Personnel Development

- Personnel Maintenance

- $\quad$ Personnel Utilization

\section{Results and discussion}

The importance of HRM can be highlighted from various perspectives. This research highlights the relevance and importance of HRM from six main perspectives, namely political, economic, legal, socio-cultural, administrative, and technological perspectives. The discussion of each perspective conceptually is as follows:

\subsection{Political Perspective}

The importance of HRM in this perspective is more directed at the macro angle, that human resources are an important asset owned by an organization starting from the macro-level (country), even internationally, to the micro-level (company). Human resources who are educated, skilled, capable, disciplined, diligent, creative, idealistic, willing to work hard, physically/mentally strong, loyal to the ideals and goals of the organization, will have a very positive effect on the success and progress of the organization. So human resources play a central and most decisive role. Without reliable HRM, the processing, use, and utilization of other resources will be ineffective, efficient, and productive.

\subsection{Economic Perspective}

From an economic perspective, people often assume that the understanding of HRM is nothing but purely economic. Such an assumption is justified by the fact that humans are often seen as a factor of production to produce goods and services by economic units. Humans cannot be equated with machines, equipment, capital, methods, and markets. Such a thing is an act that denies the fact that humans are dynamic creatures, full of love, taste, and intention. So people are the center of everything for an organization. Humans can become the center of organizational problems if their potentials are not developed and their potentials are not increased. On the other hand, humans are the center of all organizational success when all of their resources are developed fairly and convincingly.

\subsection{Legal Perspective}

Within the organization there are various regulations, provisions, or agreements, all of which regulate the rights and obligations of reciprocity between the organization and its members, between the person who employs and the person who is employed. Maintaining this balance requires clarity about the rights and obligations of each party in the organization. All that can be clear and can be realized only through a proper management system. HRM that is managed appropriately and regularly is the most relevant alternative.

\subsection{Socio-Cultural Perspective}

There are two main reasons underlying this perspective, namely

- $\quad$ First, this one side is more sensitive because it is directly related to human dignity. The opportunity to work to increase their dignity and worth. Dignity and dignity cannot be measured by things that are material but also non-physical, where work is not only to fulfill physical needs but also to realize socio-psychological needs.

- Second, it is emphasized that it is difficult to obtain a value-free HRM system. The fulfillment of sociopsychological needs is tied to social norms that apply in the society in which the person is a part. These values 
will determine whether it is good or bad, whether it is fair or not, and at the same time become a barometer of judgment for a person.

\subsection{Administrative Perspective}

This perspective emphasizes that the role of organizations in the modern era is becoming increasingly important. Modern humans are now more familiar with human proverbs organizational. Without the organization without the help of other people will not be able to realize his dreams. This dependence on others is what drives people to organize. This indicates that the progress or decline of human life depends on its ability to manage and utilize existing resources in the organization. Herein lies the relevance and importance of HRM.

\subsection{Technological Perspective}

The relevance and importance of HRM cannot be separated from sharing the developments and progress achieved in the field of science and technology. Humans are expected to be able to adapt to these various developments. For this reason, humans need to be equipped with the appropriate abilities, skills, and skills. This can only be achieved through an appropriate human resource management system.

\section{Conclusion}

The conclusions that can be drawn from the writing of this paper are as follows:

- In simple terms, human resource management is managing human resources, but in a complex way, human resource management can be carried out from a political, economic, legal, socio-cultural, administrative, and technological perspective. Of all the resources available in the organization, human resources are the most important and very decisive. All the potential of human resources is very influential on the organization's efforts to achieve goals.

- Human resource management which has six perspectives of Politics, Economics, Legal, Socio-Cultural, Administration, and Technology has three integrative functions, namely managerial functions, operational functions, and functions to achieve organizational goals in an integrated manner. Meanwhile, the duties of human resource management are staff procurement, human resource development, compensation management, occupational safety and health, labor relations, and industrial relations.

- The main objective of human resource management is to increase the contribution of human resources (employees) to the organization. It can be understood that all organizational activities in achieving its goals depend on the humans who manage the organization. Therefore, employees must be managed properly so that they can assist the organization in achieving the organizational goals that have been determined. To achieve the objectives of human resource management carried out by HR managers and managers in all lines of the organization in an integrated and integrated manner.

\section{Compliance with ethical standards}

\section{Acknowledgments}

The authors greatly acknowledge the support from Esa Unggul University, Jakarta Indonesia for providing the necessary resources to carry out this research work. The authors are also grateful to the anonymous reviewers and journal editorial board for their many insightful comments, which have significantly improved this article.

\section{Disclosure of conflict of interest}

The authors declared no potential conflicts of interest concerning the research, authorship, and/or publication of this article.

\section{References}

[1] Bandono A. The Success of Team Collaboration In Supporting Systems For Development of Project Management Learning Model. International Journal of Progressive Sciences and Technologies. 2021; 24(1): 385-393.

[2] Becker BE, Huselid MA. Strategic human resources management: where do we go from here?. Journal of management. 2006; 32(6): 898-925. 
[3] Condrey SE. (Ed.). Handbook of human resources management in government. John Wiley \& Sons. 2005.

[4] Devanna MA, Fombrun C, Tichy N. Human resources management: A strategic perspective. Organizational Dynamics. 1981; 9(3): 51-67.

[5] Gomes FC. Manajemen Sumber Daya Manusia, Yogyakarta: Andi Offset. 2016.

[6] Sule ET, Saefullah K. Pengantar Manajemen Edisi 1. Jakarta: Kencana Prenada Media Group. 2005.

[7] Kabene SM, Orchard C, Howard JM, Soriano MA, Leduc R. The importance of human resources management in health care: a global context. Human resources for health. 2006; 4(1): 1-17.

[8] Nugroho SH, Afifah S. The Relationship Of Organizational Justice And Job Embeddedness On Turnover Intention With Mediation Of Organizational Commitment. International Journal of Progressive Sciences and Technologies. $2021 ; 29(1): 335-346$.

[9] Nugroho SH, Pudiastuti ET. Analysis Of Organizational Performance Through Transformational Leadership And Organizational Culture. JOURNAL ASRO. 2021; 12(01): 46-55.

[10] Reza HK, Nugroho SH. The influence of organizational communication and leadership factors on the performance of the employee. In Sttal Postgraduate-International Conference. 2020; 4(1).

[11] Rafiei N, Davari F. The role of human resources management on enhancing the teaching skills of faculty members. Material socio-medica. 2015; 27(1): 35.

[12] Soliman F, Spooner K. Strategies for implementing knowledge management: role of human resources management. Journal of knowledge management. 2000.

[13] Sharma S, Sharma J, Devi A. Corporate social responsibility: the key role of human resource management. Business intelligence journal. 2009; 2(1): 205-213.

[14] Umar H. Strategic management in action. Gramedia Pustaka Utama. 2001. 